\title{
Quantifying the Albumin Content of 14 Tropical Maize Varieties in Ghana
}

\author{
Tetteh AY, Ayibor WG, Agyemang-Duah E* \\ Department of Biochemistry, College of Science - Kwame Nkrumah University of Science and Technology, Ghana
}

Submission: January 25, 2018; Published: April 03, 2018

*Corresponding author: Agyemang-Duah E, Department of Biochemistry, College of Science - Kwame Nkrumah University of Science and Technology, Kumasi, Ghana, Email: gigwilliam@yahoo.com

\begin{abstract}
Common maize varieties in Ghana include Obatanpa, Dobidi, Safita-2, Aburotia, Okomasa, Abeleehi, Kawanzie, Dodzi, Dorke, Abontem, Golden crystal among others. Maize contains relatively little and low quality protein compared to legumes' seeds and new studies are underway to improve their protein content which would help alleviate the problem of malnutrition. The bulk of the storage proteins in maize is prolamin, making up about $60 \%$ and glutelin which is about $34 \%$ with albumin and globulin making up about $3 \%$ each. Albumin contains essential amino acids such as lysine and tryptophan and contributes to proper growth, mental stability and to the general well-being of a person. This research seeks to determine the albumin content of fourteen (14) maize accessions for variability in their albumin contents and reveal genotypes that contain high albumin contents. The maize samples were first cleaned and prepared through various stages and finally milled into flour. The moisture content was determined using the method of A.A.C.C. The sample was also defatted in a soxhlet extractor. The albumin extraction was then carried out by the Lowry method. The morphology of the 14 maize accessions was characterized based on texture, colour and 100 -kernel weight. This was then followed by extraction of albumin. In terms of colour, $71.43 \%$ of the maize kernels were white and $28.57 \%$ yellow and in terms of texture, 57.14\% were Dent and Flint, 28.57 were Dent, Flint and Pop and 14.29\% were Flint and Pop. Hundred-kernel weight values ranged from as low as $32.73 \mathrm{~g}$ corresponding to Tzm-1117 to as high as $42.98 \mathrm{~g}$ for Okomasa. Dodzi recorded the highest albumin content $(30.678 \% \pm 2.595)$, hence a very good candidate for breeding whilst Tzm- 1117 has the lowest albumin quantity of $0.691 \% \pm 0.024$. Dodzi again recorded the highest moisture content of $8.050 \%$ and Enibi recorded the least moisture content of $4.630 \%$.
\end{abstract}

Keywords: Maize varieties; Albumin; Okomasa; Dodzi; Enibi; Ghana

Abbreviations: QPM: Quality Protein Maize; GGDP: Ghana Grain Development Program; TCA: Trichloroacetic Acid; LSD: Least Significant Difference test

\section{Introduction}

There are many maize varieties grown today after the crop was introduced by the Mexicans in pre-historic times. Selective breeding and other techniques has led to the emergence of many other varieties, some with improved qualities [1]. Common maize varieties in Ghana include Obatanpa, Dobidi, Safita-2, Aburotia, Okomasa, Abeleehi, Kawanzie, Dodzi, Dorke, Abontem, Golden crystal among others. Obatanpa and Abontem are examples of Quality Protein Maize (QPM). Most of these varieties were developed by Ghana Grain Development Program, GGDP. Maize has numerous advantages and uses which has an impact on the global food security [2].

Maize contains relatively little and low quality protein compared to legumes' seeds and new studies are underway to improve their protein content which would benefit humans [3]. Several attempts have been made to improve the amino acid balance in maize including the use of opaque-2 lysine gene [4]. A plausible method is to modulate the storage protein content with regard to albumins. The bulk of the storage proteins in maize is prolamin, making up about $60 \%$ and glutelin which is about $34 \%$ with albumin and globulin making up about $3 \%$ each. The fact that albumin is rich in lysine and tryptophan creates the need for identification of varieties that show significantly high albumin content that would contribute to the development of new varieties that contain high albumin and the others but prolamin through conventional breeding methods.

Albumin contains essential amino acids such as lysine and tryptophan and contributes to proper growth, mental stability and to the general well-being of a person [5]. Nortey [6] reported on the albumin content of some selected maize varieties and established variations in their albumin contents. It was also found that a particular maize accession contained about $63 \%$ albumin. A finding that sheds more light on the quest to provide a natural and a less expensive solution to the poor quality protein content of maize. It is hypothesized that it is possible to find maize with significantly high albumin 
content but information on the storage protein content of maize is scanty and information on storage protein content of the entire maize collection would reveal candidate genotypes for hybridization aimed at improvement in protein quality. These research works is therefore aimed at screening fourteen selected maize varieties for variability and identify those that give higher albumin content.

\section{Materials and Methodology}

Fourteen tropical maize accessions comprising landraces aquired from the Maize Germplasm Collection of IITA, Ibadan, and cultivars developed by the Crops Research Institute of the Council for Scientific and Industrial Research, Fumesua, Ghana, were used. Kernel traits including color and, texture were determined by visual inspection. One-hundred kernel mass, a measure of the compactness of kernel with respect to starch, protein and other macro components was measured on an electronic balance (OHAUS AS260D, New Jersey). Kernels were then milled and sieved to maximum particle sizes of $0.5 \mathrm{~mm}$.

Samples were defatted in a Soxhlet extractor using hexane for 16 hours. Moisture content of maize flour was determined following the method of A.A.C.C. No.16-44 7 [7] with 5g of the maize sample. Total water-soluble nitrogen-containing substances were first extracted by stirring $20 \mathrm{~g}$ of defatted flour with $200 \mathrm{ml}$ of distilled water at $4{ }^{\circ} \mathrm{C}$ for $90 \mathrm{~min}$. The mixture was centrifuged at $6000 \mathrm{rpm}$ (Mikro 220R centrifuge, Germany) for $30 \mathrm{~min}$ at $4{ }^{\circ} \mathrm{C}$. This operation was repeated with the same meal residue this time using $150 \mathrm{ml}$ of water. All the supernatants were bulked $(200 \mathrm{ml}+150 \mathrm{ml}=350 \mathrm{ml}$ total $)$. The nitrogen content of the extract was determined by the Lowry method [8]. The Lowry method combines the biuret reagent with another reagent (the Folin-Ciocalteau phenol reagent) which reacts with tyrosine and tryptophan residues in proteins. This gives a bluish color which can be read between $500-750 \mathrm{~nm}$ depending on the sensitivity required. This method is more sensitive to low concentrations of proteins than the biuret method [9].

\begin{tabular}{|c|c|c|c|c|c|}
\hline Sample & Colour & Kernel texture & HKWT(g) & Moisture (\%) & $4.630^{\mathrm{i}}$ \\
\hline Enibi & White & Flint/Dent & $33.915^{\mathrm{f}} \pm 0.247$ & $7.839^{\mathrm{d}} \pm 1.143$ \\
\hline Etubi & White & Flint/Dent/Pop & $35.205 \mathrm{e}^{\mathrm{f}} \pm 0.148$ & $7.720 \mathrm{~g}^{\mathrm{f}}$ \\
\hline Tzm -1144 & White & Flint/Dent/Pop & $38.770^{\mathrm{bcd}} \pm 0.155$ & $7.000 \mathrm{de}^{\mathrm{f}}$ & $7.313^{\mathrm{d}} \pm 1.581$ \\
\hline Tzm -1150 & Yellow & Dent/Flint & $40.155^{\mathrm{abcd}} \pm 1.647$ & $7.240^{\mathrm{cd}} \pm 0.626$ \\
\hline Obatanpa & White & Flint/Dent/Pop & $40.910^{\mathrm{abc}} \pm 0.085$ & $5.120^{\mathrm{h}}$ \\
\hline Okomasa & White & Flint/Dent & $42.975^{\mathrm{a}} \pm 0.530$ & $7.280^{\mathrm{cd}}$ \\
\hline Dodzi & White & Flint/Dent & $41.175 \mathrm{a}^{\mathrm{b}} \pm 3.840$ & $8.050^{\mathrm{a}}$ \\
\hline Aburohemaa & White & Flint & $35.205 \mathrm{~d}^{\mathrm{e}} \pm 1.181$ & $30.678^{\mathrm{a}} \pm 2.595$ \\
\hline Abontem & Yellow & Flint/Pop & $33.535^{\mathrm{f}} \pm 1.619$ & $5.310^{\mathrm{h}}$ \\
\hline Omankwa & White & Flint/Dent & $40.400^{\mathrm{abc}} \pm 0.396$ & $6.690^{\mathrm{ef}}$ \\
\hline
\end{tabular}

Albumin content in maize was determined by sequential isolation. The non-protein nitrogen-containing substances were separated from the total nitrogen-containing substances by precipitation of the water extract with Trichloroacetic acid (TCA) to a final concentration of $10 \%$ (w/v) [10]. In this method, $5 \mathrm{~g}$ of TCA was added to $50 \mathrm{ml}$ of the water extract and mixed thoroughly by stirring for $5 \mathrm{~min}$. The mixture is kept overnight at $4{ }^{\circ} \mathrm{C}$ and centrifuged at $6000 \mathrm{rpm}$ (MSE Mistral $3000 \mathrm{E}, \mathrm{UK}$ ) for 30 mins at $4{ }^{\circ} \mathrm{C}$. The supernatant was harvested and analyzed for total nitrogen by the Lowry method. In this method, $1 \mathrm{~mL}$ of the supernatant was pipetted into a clean test tube and $1 \mathrm{ml}$ $\mathrm{ml}$ of Reagent I added and incubated for 20 minutes at room temperature. After incubation, $0.5 \mathrm{ml}$ of reagent II was added and again incubated for 30 minutes. The absorbance was then measured with a UV- VIS spectrophotometer at 750nm using $1 \mathrm{~mL}$ water as a blank and the concentration deduced from the standard plot. The nitrogen measured in the supernatant is considered as non-albumin nitrogen-containing substances and the difference from the total nitrogen content of the water extract is considered as albumin material.

Means, standard deviations, standard errors and coefficient of variation were computed on triplicate measurements. Analysis of variance was computed and differences in means were located by the Least Significant Difference test (LSD). Pearson correlation was calculated. All computations were carried out using the Statistical Analysis System, SAS version 9.3.1 (SAS Institute, Cary, NC).

\section{Results}

Physical characteristics studies and chemical analysis were carried out on fourteen tropical maize varieties and accessions. The physical parameters studied included kernel color, kernel texture and hundred- kernel weight (Table 1). The moisture content and the albumin content were also evaluated. The means and variation in the hundred- kernel weight, moisture content, and the albumin contents are shown in Table 1. 


\section{Nutrition \& Food Science International Journal}

\begin{tabular}{|c|c|c|c|c|c|}
\hline Tzm-1117 & Yellow & Flint/Dent/Pop & $32.730^{\mathrm{f}} \pm 0.877$ & $7.710^{\mathrm{b}}$ & $0.691^{\mathrm{e}} \pm 0.024$ \\
\hline Kwadaso & White & Flint/Dent & $37.445^{\mathrm{de}} \pm 1.266$ & $6.550^{\mathrm{g}}$ & $7.482^{\mathrm{d}} \pm 0.270$ \\
\hline Dorke & White & Dent/Flint/Flour & $42.440^{\mathrm{a}} \pm 0.933$ & $7.070^{\mathrm{de}}$ & $23.580^{\mathrm{b}} \pm 4.341$ \\
\hline Tzm-1122 & Yellow & Flint/Pop & $38.110^{\text {cde }} \pm 0.862$ & $7.630^{\mathrm{b}}$ & $6.574^{\mathrm{d}} \pm 1.243$ \\
\hline
\end{tabular}

Alpha $=0.05, \mathrm{LSD}=2.929,0.2955$ and 4.5404 for HKWT, Moisture and Albumin respectively. Means with the same alphabets are not significantly different at 0.05 level.

Statistical analysis to compare the means and variations in the albumin content, the moisture content and the Hundredkernel weight for the 14 different accessions was done and the results are shown in Table 2.

Table 2: The Means and overall variation in hundred-kernel weight, moisture and albumin contents.

\begin{tabular}{|c|c|c|c|c|c|c|}
\hline & Mean & SD & Min & Max & $\begin{array}{c}\text { CV } \\
(\%)\end{array}$ & SE \\
\hline HKWT & 38.069 & 3.521 & 32.11 & 43.9 & 9.248 & 0.665 \\
\hline Moisture & 6.7778 & 1.0266 & 4.54 & 8.06 & 15.146 & 0.194 \\
\hline Albumin & 0.0884 & 0.0798 & 0.0006 & 0.3135 & 90.317 & 1.908 \\
\hline
\end{tabular}

The Pearson correlation analysis, which revealed the relationship between the albumin contents of the 14 varieties and their moisture contents as well as their Hundred-kernel weight and also shows how the albumin content varies with these two parameters is summarized in Table 3.

Table 3: Pearson's Correlation Coefficient, $r$, of albumin with HKWT and moisture.

\begin{tabular}{|c|c|c|}
\hline & Moisture & Albumin \\
\hline HKWT & $0.277(0.153)$ & $0.437(0.020)$ \\
\hline Moisture & & $0.163(0.407)$ \\
\hline
\end{tabular}

Pictorial representation of the variations established in the primary parameter; the albumin content of the 14 different accessions as described in Table 1 is shown in Figure 1.

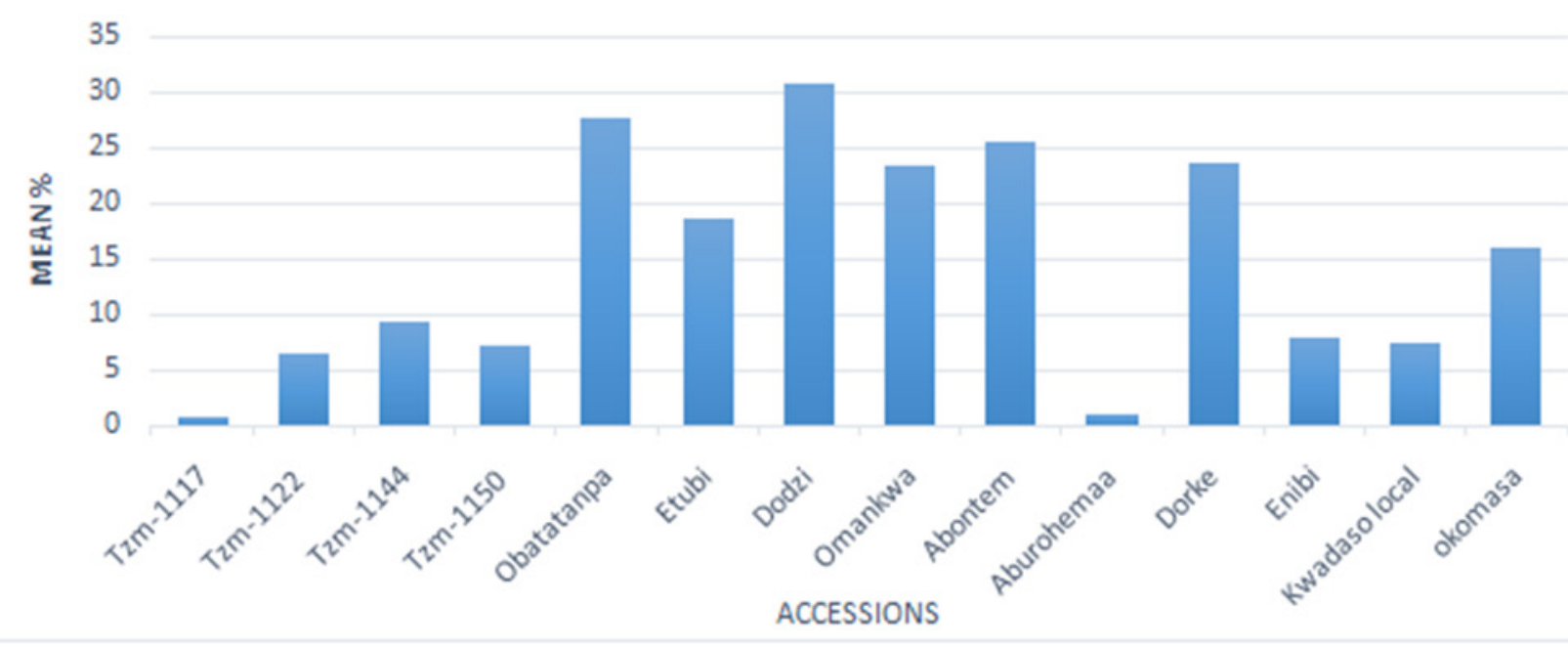

Figure 1: Variation in the albumin content of the maize accessions.

\section{Discussion}

There were variations in HKWT, moisture and albumin contents. Significant differences in HKWT, moisture and albumin were recorded among the varieties. Values of the coefficient of variation (Table 2) demonstrate low but significant diversity for HKWT (9.248\%), significant variations in moisture (15.146\%) but a high diversity for albumin $(90.317 \%)$ for all the accessions analyzed.

Visual inspection of kernels of the 14 accessions established that four were yellow, corresponding to; Tzm-1122, Tzm-1150, Tzm-1117 and Abontem. The other ten were all white. Based on morphology, six out of the fourteen kernels were of the flint and dent type, corresponding to; Enibi, Tzm-1150, Omankwa, Okomasa, Dodzi and Kwadaso Local. Four out of the fourteen kernels had mixed textures (flint, dent and pop), namely; Etubi, Tzm-1144, Obatanpa and Tzm-1117. Only one of them, Aburohemaa had a single texture, which was flint. Abontem and Tzm-1122 were flint and pop. Dorke had a denty, flinty and floury texture. Kernel colour and texture is not known to affect the chemical composition of maize but can affect storage properties and processing. Floury kernel for example is expected to pose fewer problems during processing than the others but more prone to insect damage in storage than 
flint type which exhibits less risk of spoilage in shipping and storage maize since hard kernel absorbs less moisture. Also the flint kernel maize is more resistant to fungi and insect damage when compared with the dent maize. It can grow easily to higher latitudes than other forms of maize. This maize can be found in different colours, such as white yellow, red-blue, etc.

The value of the coefficient of variation established low diversity for HKWT $(9.248 \%)$. One-hundred kernel weights is a measure of the compactness of kernel with respect to starch, protein and other macro components of the seed and is an essential determinant of the nutritional value and as such the economic value of the maize. It should not be expected that all the maize varieties would have similar hundred-kernel weight, due to different climatic conditions and genetic variability among the different accessions. The CV value obtained showed low but significant variations in the Hundred- kernel weight among the accessions. The mean values ranged from as low as $32.730 \pm 0.877$, corresponding to Tzm-1117 to a highest value of $42.975 \pm 0.530$, for Okomasa. It can then be deduced that Okomasa is predicted to be the most nutritious of all the maize accessions hence would be given more preference whilst Tzm1117 is otherwise.

From Table 2, the moisture content of maize accessions ranged from as low as $4.630 \%$ to $8.050 \%$ corresponding to Enibi and Dodzi respectively. The coefficient of variation established that there was a low but significant variation in the moisture content of the fourteen accessions. Aisha \& ElTinay [11] found the moisture content of 12 corn genotypes within the range of 4.3 to $6.7 \%$. Studies conducted by Tetteh et al. [12] on tropical Zea mays accessions and cultivars in Ghana also recorded moisture content of $5.5 \pm 0.03$ to $6.7 \pm 0.0 \%$. Comparison of the results of these independent studies shows some similarity and consistency in the moisture contents of different maize varieties and accessions. It should however be noted that, in contrast to these results, Dorsey-Redding et al. [13] reported high moisture contents of ten maize hybrids within the range of 8.43 to $22.77 \%$. Climate and drying times can affect the moisture content of cereals and as such maize but it is not generally expected that maize should have very high moisture content, especially, the landraces.

The albumin content of the maize accessions analyzed showed significantly high variations as shown in Table 1 \& Figure 1. The values ranged from as low as $0.691 \pm 0.024$ to $30.678 \pm 2.595$ corresponding to Tzm-1117 and Dodzi respectively. Usually, it is not expected that maize would have very high albumin content such as seen in Table 1 of some of the accessions although climatic conditions and difference in ecology can have a significant impact on the chemical and nutritional composition of crops. Variation in planting times and nutrient availability could also account for the wide variation witnessed in the albumin contents. The variation coefficient of more than $90 \%$ obtained could also be due to errors in the procedure employed. The fact however remains that variation in albumin exist among the different accessions studied and this seems to provide hope for more analysis on the albumin content of different varieties and accessions as this would pave the way for breeding high quality protein maize with improved content of lysine and tryptophan. Based on these results, Etubi, Obatanpa, Dodzi, Omankwa, Dorke and Abontem can further be analyzed to ascertain their albumin levels since they all recorded significantly high albumin content, thus meets the objective of this research.

According to Hansel et al. [14] increase in albumin, globulin and the glutelin contents is a positive indicator of reduced prolamin content. Thus cross-breeding methods involving high albumin maize and low prolamin maize is a cheap alternative to other expensive and usually destructive methods employed to correct the amino acid imbalance anomaly in maize.

Correlation analyses between albumin, moisture and 100-kernel weight were performed as shown in Table 3. Positive but insignificant correlations were observed between albumin content and hundred-kernel weight (0.437) and moisture content (0.163), suggestive that, albumin content increases with increasing 100-kernel weight and moisture content and vice versa. The correlation studies established that, about $19 \%$ of the variations in albumin content of the fourteen accessions can be accounted for by the HKWT.

\section{Conclusion}

Analysis of fourteen maize accessions established wide variation in the albumin content. Etubi, Obatanpa, Dodzi, Omankwa, Dorke and Abontem showed high albumin contents with Dodzi especially demonstrating the highest level (30.678\%). Accession Tzm-1117 recorded the least albumin content with $0.691 \%$. The wide variability in albumin contents can therefore be exploited for the breeding of high quality protein maize by selective breeding. Dodzi, which contained the highest albumin, is therefore a good candidate for breeding. It also suggests reduced prolamin content but has a lot of the other storage proteins (glutelin and globulin) rich in essential amino acids too.

\section{Recommendation}

Since we Ghanaians and most Africans depend on maize a lot, more research into the albumin content of other different varieties of maize should be carried out using other equally good and more sensitive assay procedures like the Micro Lowry to augment these findings in a bid to improve upon the protein quality of maize. Analysis of the albumin content of those accessions that demonstrated unusually high levels of albumin, chiefly among them, Dodzi, is therefore recommended.

\section{References}

1. Brown WL, Zuber MS, Danah LL, Glover DV (1985) Origin, adaptation andt types of corn. National Corn Hndbook 10(1): 1- 6.

2. Pimentel D, McNair M, Buck L, Pimentel M, Kamil J (1997) The value of forests to world food security. Human Ecology 25(1): 91-120. 
3. Glover DV, Mertz ET (1987) Corn: Nutritional Quality of Cereal Grains: Genetic And Agronomic Improvement. Agronomy Monograph 28. ASACSSA-SSSA, Madison, USA, pp. 183-336.

4. Schmidt RJ (1993) Opaque-2 and zein gene expression. In: "Control of Plant Gene Expression”. Verma DPS (Eds.), CRC Press, Inc., Kualalumpur, Malaysia pp. 337-355.

5. Arthur L (2010) Introduction to Protein Sciences; Architecture, Function and Genomics, $2^{\text {nd }}$ edn, Oxford University Press, London, UK, pp. 178.

6. Nortey BAE (2014) Storage protein profile of tropical maize varietiesalbumins. Undergraduate Research project Dissertation. Department of Biochemistry and Biotechnology, KNUST, 1: iv

7. AACC (2000) Approved methods of the American association of cereal chemists. Methods 54: 21.

8. Lowry OH, Rosebrough NJ, Farr AL, Randall RJ (1951) Protein measurement with the Folin phenol reagent. J Biol Chem 193(1): 265275.

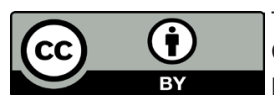

This work is licensed under Creative Commons Attribution 4.0 License DOI: 10.19080/NFSIJ.2018.06.555680
9. Everette JD, Bryant QM, Green AM, Abbey YA, Wangila GW (2010) Thorough study of reactivity of various compound classes toward the Folin-Ciocalteu Reagent. J Agric Food Chem 58(14): 8139-8144.

10. Landry J, Delhaye S, Goiai L (1999) Protein distribution in gluten products isolated during and after wet-milling of maize grains. Cereal Chemistry 76(4): 503-505.

11. Aisha FS, El-Tinay AH (2004) Effect of genotype, malt pretreatment and cooking on in vitro protein digestibility and protein fractions of corn. Food chemistry 84(4): 613-619.

12. Tetteh AY, Bahaah B, Adu-Gyamfi L, Amadi R, Sekyere M, et al. (2013) Determining the potential to breed for enhanced protein content in West African maize accessions: mean inter varietal protein content. $28^{\text {th }}$ Biennial Conference of the Ghana Science Association, Ghana.

13. Dorsey-Redding C, Fox SR, Johnson LA, Hurburgh CR, Bailey TB (1992) Relations of grain proximate composition and physical properties to wet-milling characteristics of maize. Cereal chemistry 69(2): 191-197.

\section{Your next submission with Juniper Publishers will reach you the below assets}

- Quality Editorial service

- Swift Peer Review

- Reprints availability

- E-prints Service

- Manuscript Podcast for convenient understanding

- Global attainment for your research

- Manuscript accessibility in different formats

( Pdf, E-pub, Full Text, Audio)

- Unceasing customer service

Track the below URL for one-step submission https://juniperpublishers.com/online-submission.php 